This document is the Author Original Manuscript.

Please cite the publisher's Version of Record:

Field, S. L. (2021, forthcoming). 'The Politics of Being Part of Nature'. Australasian

Philosophical Review.

Australasian Philosophical Review

\title{
The Politics of Being Part of Nature
}

Sandra Leonie Field

Yale-NUS College

Author Note

Sandra Leonie Field, Assistant Professor of Humanities (Philosophy), Yale-NUS College, Singapore. Address for correspondence: Sandra Field, c/o Elm Rector's Office, Yale-NUS College, 12 College Ave West, \#01-201, Singapore 138610. Contact: sandra.field@yalenus.edu.sg

PhilPeople: https://philpeople.org/profiles/sandra-field

ORCID: 0000-0002-2915-6258 


\section{The Politics of Being Part of Nature}

Abstract: Genevieve Lloyd argues that when we follow Spinoza in understanding reason as a part of nature, we gain new insights into the human condition.

Specifically, we gain a new political insight: we should respond to cultural difference with a pluralist ethos. This is because there is no pure universal reason; human minds find their reason shaped differently by their various embodied social contexts.

Furthermore, we can use the resources of the imagination to bring this ethos about. In my response, I offer a friendly challenge to Lloyd's characterisation of the lessons of Spinoza's philosophy. I argue that Lloyd's Spinoza remains excessively unpolitical, even in the moment that he is brought to bear on contemporary politics. An unpluralistic attitude may well be rationally inferior, but is it really explained by insufficient or inappropriate imagination? To the contrary, a properly Spinozist account of reason must include an account of the concrete determinants of reason's imperfect realisation in the world. In Spinoza's own oeuvre, this is carried out through an ever-increasing-and ever more sociological-interest in the political structures within which individual reason flourishes or withers.

Keywords: Spinoza; rationalism; politics

Stretching back decades, Genevieve Lloyd's writings on Spinoza have cut through the forbidding metaphysical density of the seventeenth century philosopher's texts, ${ }^{1}$ bringing to the fore their contemporary significance, not just for philosophy, but also for our condition as living embodied human beings. ${ }^{2}$ 'Reconsidering Spinoza's "Rationalism"'13 recapitulates these achievements through a focus on the concept of ratio (reason). Human reason is central to Spinoza's philosophical system, but reason must be understood, like everything else, as a part of nature. For Spinoza there is no philosophical transcendence; Lloyd uses this idea as a red thread to link together Spinoza's different texts and to understand the relation of his thought to existential questions, artistic pursuits, and contemporary politics. Human minds, always

\footnotetext{
${ }^{1}$ Benedictus de Spinoza (1972), Spinoza Opera, edited by Carl Gebhardt. Heidelberg: Carl Winter. (1994), 'Ethics,' in A Spinoza reader: the Ethics and other works, edited by Edwin M. Curley (Princeton: Princeton University Press), 85-265. [=E]

(2000), Political Treatise, translated by Samuel Shirley (Indianapolis: Hackett). [=TP] (2001), Theological-political treatise, translated by Samuel Shirley (Indianapolis: Hackett). [=TTP]

${ }^{2}$ Genevieve Lloyd (1994), Part of nature: self-knowledge in Spinoza's Ethics (Ithaca: Cornell University Press); Genevieve Lloyd (1996), Spinoza and the Ethics (London; New York, NY: Routledge); Moira Gatens and Genevieve Lloyd (1999), Collective imaginings: Spinoza, past and present (London: Routledge); Genevieve Lloyd (2008), Providence Lost (Cambridge, MA: Harvard University Press), Chapter 6; Genevieve Lloyd (2009), 'Dominance and Difference. A Spinozist Alternative to the Distinction Between 'Sex' and 'Gender", in Moira Gatens (ed.), Feminist Interpretations of Spinoza (Pensylvania), 29-41.

${ }^{3}$ Genevieve Lloyd (2020 forthcoming), 'Reconsidering Spinoza's "Rationalism"', Australasian Philosophical Review.
} 
and unavoidably immersed in nature, struggle for understanding, and they make use of imagination, emotion, and art to assist them in this struggle. Spinoza's key contribution to contemporary politics, on Lloyd's retelling, is the insight that human minds find their reason shaped differently by their various social contexts, facilitating a pluralism about reason without subjectivism. In consequence, we should respond to cultural difference with a pluralist ethos, and we can do so by engaging with the appropriate Spinozist imaginative frames.

In my response I would like to offer a friendly challenge to Lloyd's characterisation of the lessons of Spinoza's philosophy. In so doing, I must acknowledge my debt to her work. It was her Part of Nature (1994) that piqued my interest in Spinoza in the first place, in particular her reflections on the emergent nature of individuality. ${ }^{4}$ But it seems to me that her portrait of Spinozist reason does not fully carry through on the striking potentialities that her own exegesis sets up, and consequently it neglects a key component of Spinoza's view. Specifically, I will argue that Lloyd's Spinoza remains excessively unpolitical; he remains excessively unpolitical even in the moment that he is brought to bear on contemporary politics. I will adduce both textual and conceptual considerations to support my claim. In a nutshell, if human reason is part of nature, then the response to its very imperfect realisation in ordinary human life-and in particular, to the all-too-common failure to achieve an egalitarian pluralist ethos-cannot simply be (as it sometimes seems to be for Lloyd, in a sense that I will explain) to call for people to choose to reason better, to be more philosophical. For where is the substantial self that might make that choice? Rather, a properly Spinozist response to reason's imperfect realisation in the world must focus on its concrete determinants; across Spinoza's own oeuvre, this is carried out through an ever-increasing-and ever more sociological-interest in the political structures within which individual reason

\footnotetext{
${ }^{4}$ Lloyd, Part of nature, 10-16.
} 
flourishes or withers. I hope that the outcome of this friendly challenge will be to underscore all the more sharply the contemporary relevance a Spinozist conception of reason.

\section{The Lessons of Spinoza's Philosophy}

Lloyd's article, like all her writings on Spinoza, draws out the human significance of Spinoza's philosophical system. Spinoza's most striking metaphysical commitmentconceiving of humans and their reason as part of nature-generates a new approach to difficult problems of the human condition. I focus on two of the problems which Lloyd suggests this metaphysics can illuminate: existential dread; and cultural-political pluralism. But there is a tension: the very thinking minds that are called upon to have a more Spinozist understanding of existence and of pluralism are themselves part of nature. As such, they are not substances endowed with a free capacity for spontaneous choice. Lloyd herself foregrounds this tension and offers a response; but in the following section, I will suggest her response does not go far enough.

The first problem is the dread of infinite spaces. Nature is so vast; if we meditate upon nature's infinite totality, we are struck by how profoundly insignificant and ephemeral we are in comparison. Both Pope and Pascal escape this dread by resisting the subsumption of humans within nature. Pope has faith that the universe's infinite totality is actually ordered to human purposes; Pascal finds ground for human superiority over nature in the human capacity for thinking and the human access to life beyond death. ${ }^{5}$ Spinoza takes a different route. For Spinoza also, dread is unnecessary, but not because humans are above nature. Humans-including their reason-are truly a part of nature. But joy can come from the very activity of human reason to better understand its own finitude and interdependence with other

\footnotetext{
${ }^{5}$ Lloyd, 'Reconsidering Spinoza's "Rationalism"', 13-18.
} 
things; when fully developed, this understanding is intuitive knowledge, or-to use equivalent Spinozist jargon-the 'intellectual love of God'. ${ }^{6}$

The second problem is cultural and political pluralism. In human social life, we are constantly confronted by individuals and groups with differing perspectives and judgements from our own. This experience of plurality is particularly intense in the 21 st century, as transnational connections, mass migration, and the legacies of colonialism force diverse cultures in contact with one another. ${ }^{7}$ One possible response to this plurality would be to identify one voice as the voice of reason. Familiar examples of such a response include privileging modern science over Indigenous knowledge, which is dismissed as myth or superstition; or privileging 'western values' as universal and true, over other merely particularistic and historical cultures. But Lloyd claims that Spinoza offers a different response: 'attempting to engage with Spinoza may help to break the grip of familiar triumphalist narratives of the supremacy of human reason'. ${ }^{8}$ For Spinoza, our reason-being part of nature-is an emergent phenomenon, shaped and formed through experiences. Reason does not generate itself purely, but rather it is scaffolded and enduringly enmeshed with narratives and forms of imagination. This means that reasoning always remains 'situated reasoning'. ${ }^{9}$ The actually existing reason of any human being retains the stamp of their particular history of experience. Once we recognise how reason is constituted, we see that there is knowledge and rationality even in diverse and unfamiliar cultural forms, and that the dominant voice is not universal. The Spinozist conception of reason is pluralist without being

\footnotetext{
${ }^{6}$ Ibid., 18-19; Lloyd, Part of nature.

${ }^{7}$ Lloyd, 'Reconsidering Spinoza's "Rationalism"', 33-35.

${ }^{8}$ Ibid., 33

${ }^{9}$ Idem. See also Gatens and Lloyd, Collective imaginings, 25-26, 90.
} 
relativist, because of the irreducible particularity of how reason is constituted. ${ }^{10}$ Accordingly, a Spinozist will embrace multiculturalism and cultivate respect for diverse forms of knowing.

Thus, on Lloyd's account, through a good Spinozist understanding of the world, people can find existential peace of mind (case 1), and become tolerant and inclusive (case 2). But how do they achieve this good understanding? For many other philosophers, the question would be a trivial one: once a standard of good reasoning is posed, it is up to individuals to rise to that standard. But for Spinoza, the question is not trivial. The human mind and its reason are parts of nature. Lloyd emphasises that reason is fragile, incompletely formed, and vulnerable to hostile forces. ${ }^{11}$ We need an account of how reason emerges and progresses: Lloyd proposes that cultivation can occur through reason interacting with other less pure forms of thought: 'the power of reason is cultivated by exploiting its connections with imagination and emotion, rather than suppressing them'. ${ }^{12}$ Three striking mechanisms for minds to progress towards good Spinozist reason are laid out in her article. First, philosophical imaginative ideas. Even in the Ethics, Spinoza's supposedly most rationalist and deductive work, Lloyd shows that Spinoza explicitly recommends using feigning (that is, deploying imaginative fictions), to assist ascent to the ultimate philosophical achievement of intellectual love of God. ${ }^{13}$ Second, the immediate experience of philosophical texts. Lloyd draws attention to the remarkable resonance of Spinoza's texts with non-philosophers: they have an affective impact, even for those who do not have a full grasp of their specific theses and arguments. ${ }^{14}$ Third, literature and art. Lloyd defends imprecise artistic engagement with

\footnotetext{
${ }^{10}$ This thesis regarding multicultural reason echoes Lloyd's earlier work on gender: according to which the different lived experiences of women compared to men gives rise to a different characteristic female rational voice. See Lloyd, Part of nature, 160-62; Lloyd, 'Dominance and difference', 34-35.

${ }^{11}$ Lloyd, 'Reconsidering Spinoza's "Rationalism"', 10-13.

${ }^{12}$ Ibid., 11.

${ }^{13}$ Ibid., 20-22.

${ }^{14}$ Ibid., 22-23.
} 
Spinoza's texts, such as Flaubert's, as providing an imaginative rendering of the Spinozist vision of mind-in-world. ${ }^{15}$

\section{A Necessary Supplement}

In this section, I propose a necessary supplement to Lloyd's discussion of Spinoza's reason. It is a characteristic professional prejudice of philosophers to focus on the power of individual rationality. Lloyd departs from the sterility of a narrow conception of reason, insofar as she devotes attention to a broader set of determinants of thought, as discussed above. But even so, I will now argue that Lloyd remains firmly in the domain of individual self-cultivation, and that a fully Spinozist account of reason cannot afford to do so. Beyond narrative, art, and imagination, Spinoza's texts suggest quite a different set of factors being relevant to reason: I am referring to social relations and political institutions. The progress of reason is sustained and encouraged by certain material conditions, and not others. ${ }^{16}$ This is an interesting and striking feature of Spinoza's conception of reason that is missing from Lloyd's account.

In the discussion that follows I will focus on one key feature of good Spinozist reason: its attitude of pluralism and tolerance. Lloyd's account of the progress of reason towards this goal is focussed on self-improvement through contact with suitable cultural and intellectual materials. Experience great literature and art! Listen to cultural narratives! Invent and deploy imaginative exemplars! Such contact does not guarantee that good Spinozist reason is actually achieved. I take it that Lloyd understands herself to be offering its necessary but not sufficient conditions: she grounds the possibility of an improvement of reason. The encounter with the Spinozist perspective 'opens up possibilities for thought to move in new directions'. ${ }^{17}$

\footnotetext{
${ }^{15}$ Ibid., 24-27.

${ }^{16}$ Or to formulate more precisely, the material correlates of a subject's rationality rely upon broader material conditions beyond the confines of the subject's body. See the discussion of 'parallelism' below.

${ }^{17}$ Lloyd, 'Reconsidering Spinoza's "Rationalism"', 33, emphasis added.
} 
The critical question for Lloyd's interpretation is whether her account of the possibility of reason is sufficient, given the requirements of Spinoza's philosophical system. Spinoza holds uncompromisingly to the view that nothing is genuinely contingent.

[I]f they [the modes of the divine nature] have been determined by God, it is not contingent, but impossible, that they should render themselves undetermined. So all things have been determined from the necessity of the divine nature, not only to exist, but to exist in a certain way, and to produce effects in a certain way. $(E 1 p 29 d)^{18}$

We may usefully retain the terms 'contingency' and 'possibility', not to indicate the nature of reality, but only in a secondary sense: indicating a limitation of our knowledge. To the extent that the order of causes of a certain future effect is hidden from us, we do not know whether the effect will or will not occur; we don't know whether it is necessary or impossible (E $1 \mathrm{p} 33 \mathrm{~s} 1,2 \mathrm{p} 44)$. It is only in respect of this kind of ignorance that it is permissible to speak of possibility.

Let me apply these considerations back to Lloyd's discussion. The effect in question is the progress of reason, to achieve pluralism and tolerance. Sometimes, human reason does progress. From time to time, we see exemplars of the required pluralist ethos. But equally, sometimes undesirable anti-plural views emerge and even prevail. Indeed, 'it is not in every man's power always to use reason and to be at the highest pitch of human freedom' (TP 2.8). Prima facie, it is not clear what accounts for these different outcomes. The causality of human thought seems to be so complex that it is hard to say with any precision what determinate form it will take for a given individual. Perhaps exposure to supportive narratives plays some role in generating the desired outcome. But individuals find themselves confronted with many different possible narratives, and mere quantitative exposure alone does not determine which narrative sticks: some people like Spinoza and Flaubert, others do not. Thus although in fact the progress of reason of any particular individual is either necessary or impossible, we do not know this in advance.

${ }^{18}$ See also E 1p26-29. 
If this were as much as we could say about what leads to a Spinozist pluralist attitude rather than a supremacist one, then we would be entitled to make the unqualified claim that the progress of reason to the pluralist attitude is possible. But are we really unable to make any advance on this very limited grasp of the determinate causes of human thought? Or is it rather that we find comfort in treating these causes as unknowable, and as a result we refuse to engage in deeper investigations of the genesis of who we are and how we behave and think? Spinoza suspects the latter (E 1App, 3p2s; TP 1.1, 2.6), and he sets himself the task of developing a superior understanding.

I have taken great care not to deride, bewail, or execrate human actions, but to understand them. So I have regarded human emotions such as love, hatred, anger, envy, pride, pity, and other agitations of the mind not as vices of human nature but as properties pertaining to it in the same way as heat, cold, storm, thunder, and such pertain to the nature of the atmosphere. These things, though troublesome, are inevitable, and have their definite causes through which we try to understand their nature. (TP 1.4; see also E 3Pref)

To this end, Spinoza's strategy, carried out in the most detail in his two political tracts, is to change the frame of reference. Where individual outcomes may be unpredictable, populationlevel effects are more amenable to investigation. What leads a good Spinozist attitude to become prevalent, or not, across a population? Spinoza's answer, missing in Lloyd's reconstruction, ${ }^{19}$ is political institutional conditions: with this answer in hand, it will no longer be legitimate to speak of the unqualified possibility of rational improvement.

The Preface to Spinoza's Theological-Political Treatise (=TTP) offers a sharp analysis of the relation of external political conditions to reason. The immediate topic is an inquiry into the origins of superstition in a population. Spinoza argues that insofar as people are in control of their lives, they are not prey to superstition at all. But lacking that control, the intense passions generated by insecurity destroy reasoning, leading to credulity, from which superstition is only a short step away.

\footnotetext{
${ }^{19}$ Missing, that is, in the present lead article. The topic receives some attention in Collective imaginings (Gatens and Lloyd, Collective imaginings, 114-31); however, my point is that it is a necessary and indispensible aspect of a Spinozist conception of reason, especially one foregrounding the idea of 'being part of nature'.
} 
But since [people] are often reduced to such straits as to be without any resource, and their immoderate greed for fortune's fickle favours often makes them the wretched victims of alternating hopes and fears, the result it that, for the most part, their credulity knows no bounds. In critical times, they are swayed this way or that by the slightest impulse, especially so when they are wavering between the emotions of hope and fear; yet at other times they are overconfident, boastful and arrogant. [... I]n adversity they know not where to turn, begging for advice from any quarter; and then there is no counsel so foolish, absurd or vain which they will not follow' (TTP Pref/1).

Their credulity can readily be captured by ambitious false prophets, and harden into religious instability (TTP Pref/2-4); a feedback cycle of intense affects deepens hostility and mistrust (E 3p11-3p35). Thus, gross fluctuations of fortune can generate and sustain failures of rationality. A key plank of Spinoza's solution to these failures is to stabilise fortune through politics. The purpose of the state is 'to free every man from fear so that he may live in security as far as possible' (TTP 20/223), both fears about violence from fellow citizens and fears of larger forces beyond the body politic.

From this case, it might seem that the relation of politics to reason is merely external sufficiency: politics must remove gross insecurity, but once a threshold of security is achieved, politics has no further influence on reason's development. However, to the contrary, I claim that for Spinoza, politics and reason are more pervasively enmeshed. This is because there is no simple or easy way to reach the required threshold of security. Ensuring political security is a very complicated business, dependent on the ongoing compliance of the greater part of the population of a state. Spinoza has no patience for the stylised Hobbesian model of security achieved once and for all by a sovereign with a big sword.$^{20}$ For even under the rule of such a sovereign, subjects may experience affects which will unravel security over time. Everyone knows that subjects can still be roiled 'by dissatisfaction with their lot and desire for change, by hasty anger, by disdain of poverty, and how their minds are engrossed and agitated by these emotions' (TTP 17/187). In Spinoza's view, these affects are neither brute givens nor random occurrences, but rather, they are sociological products of a society's

\footnotetext{
${ }^{20}$ Benedictus de Spinoza, Letter 50, in Spinoza Opera (Vol IV), $239 \mathrm{~b}$.
} 
structure. The state and society in which people live shapes how they live their lives, how they understand their connections and obligations, how and towards whom they feel solidarity or hostility, how and with whom are they willing to cooperate. In the TheologicalPolitical Treatise, Spinoza observes that 'minds are to some degree under the control of the sovereign power, who has the means of inducing the great majority to believe, love, hate etc. whatever he wills' (TTP 17/186). Even this account of political causality is too narrow; in his Political Treatise, Spinoza shifts his focus away from the sovereign's will and towards the laws, taken in an expansive sense to include a society's political and economic structure.

For it is certain that rebellions, wars, and contempt for or violation of the laws are to be attributed not so much to the wickedness of subjects as to the faulty organisation of the state. Men are not born to be citizens, but are made so. (TP 5.2)

But just as the vices of subjects and their excessive licence and wilfulness are to be laid at the door of the commonwealth, so on the other hand their virtue and steadfast obedience to the laws must be attributed chiefly to the virtue and the absolute right of the commonwealth (TP 5.3; see also TTP 17/187)

Human behaviour, for better or worse, can only be understood in political context.

This point can be illustrated by some Spinozist examples. First, sectarianism.

Sectarianism can be fatal to political security. But on Spinoza's analysis, sectarianism is not an intrinsic feature of a religiously diverse population. Rather, it is generated by an inappropriate political decision structure, in which civil magistrates attempt to settle theological questions (TTP 20/227). Second, recalcitrance. The ancient Hebrews saw their state fall apart due to their disobedience and 'stiff neck'; but on Spinoza's analysis, this is not an innate feature of their national character. Rather, the Hebrews increasingly forsook the law because of their envy following on bad institutional design: the elevation of the Levites above the other tribes of Israel (TTP 17/200-203). Third, aristocracy. Whereas the forgoing two examples concern institutional design undermining the security of the state and thereby indirectly weakening the population's reason, this third example concerns institutional design which durably achieves security, but which directly counters the progress of reason. Spinoza 
analyses aristocracy as a secure regime, but one which rests on and consolidates jealousy of recent immigrants (TP 8.12). As such, it does not conduct to a pluralist attitude towards the value of diverse perspectives within the community.

In drawing attention to the contribution of political institutions to the development of Spinozist reason, I do not mean to deny Lloyd's contention that narratives and imaginative frames also play a role. Indeed, Spinoza himself argues that good doctrines lead to devotion, peace, and harmony (TTP 5/68, 14/163). But taken as an overall characterisation of Spinozist reason, Lloyd's contention remains very partial. Narratives have little independent motive force; they will stick and be efficacious only if they match the affects and understanding of their audience (TTP 5/66), but this in turn is determined by that audience's institutional or structural context (see for instance TTP 18/209-10). This is why certain forms of life lead to certain characteristic forms of understanding, as Lloyd observes in her discussion of the differences of reasoning evident in different cultural groups. However, the observation equally applies also to what is, from Spinoza's and Lloyd's point of view, better and worse reasoning (more pluralist or more intolerant reasoning). ${ }^{21}$ Thus, a population's reasoning cannot be improved just by posing alternative narratives, unless the underlying form of life supports the affective and imaginative shape of that narrative.

Let me now tie this discussion back to the question of whether we can say the progress of reason is possible. Spinoza insists

we cannot have the slightest doubt that, if it were equally in our power to live at reason's behest as to be led by blind desire, all would be led by reason and would order their lives wisely, which is by no means the case. (TP 2.6)

\footnotetext{
${ }^{21}$ Lloyd herself acknowledges an analogous point regarding gendered reason. Between male and female reasoning, there is both lateral diversity-different lived experience gives rise to different but not inferior forms of imagination (see footnote 10 above)-but also there is hierarchical diversity. Concrete personal dependency has its corollary in deficient or stunted reasoning. (Lloyd, Part of nature, 164; Lloyd, 'Dominance and difference', 36-38.)
} 
Granted, it may be possible (for all we know) that any particular individual may develop their reason; indeed, even under the most adverse political circumstances, some exceptional individuals may do so. Nonetheless, as a matter of social theory, we know that for the most part, the shape of people's reason, and whether it advances or not, depends on political conditions. Consequently, it is not legitimate to say that it is possible that a whole population to develop reason, unless we qualify the claim with the requirement that the political conditions be conducive. Hence, to speak of the improvement of reason without taking this point into account comes perilously close to invoking free moral action, as though people can choose to be rational through their own free volition.

\section{Worries About the Turn to Politics}

Philosophical readers of Spinoza may meet my argument with skepticism. I can imagine two principal objections. First, it may be objected that I have only shown that politics has a role in generating the orderliness of subjects, not their reason. Second, it may be objected that whatever the merits of my criticism of self-cultivation, it cannot be accepted by Spinoza, given his ample textual treatment of self-cultivation in the Ethics.

My first objector might point out that the arguments and textual materials from my previous section do not exactly connect politics with reason per se, but rather with political virtue and good citizenship, or in other words, orderliness. The materials show that Spinoza holds that politics can bring individuals to live in accord with reason (E 4p40d), but does politics have any role in them living from reason? Or does politics merely bring superficially similar behavioural and affective outcomes through the external mechanisms of inducement and threat? Against my posited connection between reason and politics, my objector might insist that reason must be active; internal cultivation is necessary.

I can grant all this without damage to my argument. For to be clear, it is not my purpose to claim that politics is a sufficient determinant of rationality. My purpose, rather, is 
to insist that politics is a necessary condition for the widespread prevalence of rationality in a population. Negatively, Spinoza shows how politics can readily thwart the advance of reason. This is not merely true of outlandish cases such as ancient superstitious theocracies as in the Preface of the Theological-Political Treatise (TTP Pref/2-3, 17/187-88). Closer to home, the bad political structure of contemporary states can elevate sycophancy and can corrupt honest discourse (TTP 20/226-229); or can deepen division within the polity (my examples from the previous section). But positively, Spinoza himself constantly lays out politics as support to rationality. The state enables subjects 'to develop their mental and physical faculties in safety, to use their reason without restraint and to refrain from the strive and vicious mutual abuse that are prompted by hatred, anger or deceit' (TTP 20/223). The best state is one where the population can develop 'reason, true virtue, and the life of the mind' (TP 5.5). Granted, the external causation of politics cannot directly produce rationality, because rationality is an inner active strength. But an emergent line of scholarship stresses the role of good external conditions in scaffolding internal development. ${ }^{22}$

Indeed, we can build on some of Lloyd's own exegesis to understand the scaffolding relation between external causation and inner active rationality. Lloyd's reconstruction of Spinoza's conception of reason draws attention to its imbrication with bodily experience. ${ }^{23}$ Spinoza holds that thought and extension do not causally interact, but rather, are parallel attributes of a single substance. As Spinoza explains, '[t]he order and connection of ideas is the same as the order and connection of things'. (E 2p7) This has immediate application for understanding the human body:

\footnotetext{
${ }^{22}$ See Steinberg's discussion of the role of the state in individual ethical development, and in Deleuze's account of the progress from joyful passions to active joys. Gilles Deleuze (1992), Expressionism in Philosophy: Spinoza, trans. Martin Joughin (New York: Zone Books) 239-246, 257-65, 273-88; Justin D. Steinberg (2009), 'Spinoza on civil liberation', Journal of the History of Philosophy, 47 (1); Simon Duffy (2011), 'The Joyful Passions in Spinoza's Theory of Relations', in Dimitris Vardoulakis (ed.), Spinoza Now (Minneapolis: University of Minnesota Press), 51- 64. See also Gatens and Lloyd, Collective imaginings, 54.

${ }^{23}$ Lloyd, 'Reconsidering Spinoza's "Rationalism"', 7-9. See also Lloyd, Part of nature, 27-30.
} 
[T] he mind and the body are one and the same thing, which is conceived now under the attribute of thought, now under the attribute of extension. The result is that the order, or connection, of things is one, whether Nature is conceived under this attribute or that; hence the order of actions and passions of our body is, by nature, at one with the order of actions and passions of the mind. (E 3p2s)

This means that the rationality of the mind must be characterisable also at the material level of the body. Lloyd proposes that what it is for a human to be rational is for the body to maintain its own characteristic 'ratio', or distinctive proportion of motion and rest, in the face of many and diverse experiences. ${ }^{24}$ The contrast is a person who is battered by external events, unsettled by encounters with people different from themselves, and more generally in the thrall of their passions: they are under the control of fortune and not of themself (E 4Pref).

Thus the challenge of developing human reason is coextensive with the challenge of developing a robust self-maintaining ratio. But the first step on the way to a robust selfmaintaining ratio is to establish any ratio at all. Think for instance of the raising of children. Good parents and teachers protect children from abuse and want, and externally constrain them to certain scripts of behaviour; the children may then subsequently develop internal self-regulation to stay this course. Politics plays a similar role on a grander scale. When politics mitigates hostile pressures on an individual and coaxes the individual's conduct to conform to a certain externally rational mould, it helps the individual to establish a characteristic ratio. It is from this groundwork that an individual has the opportunity to grow an inner robustness to maintain this ratio themselves. ${ }^{25}$

\footnotetext{
${ }^{24}$ This gloss has ample textual basis: 'in proportion as a body is more capable than others of doing many things at once, or being acted on in many ways at once, so its mind is more capable than others of perceiving many things at once. And in proportion as the actions of a body depend more on itself alone, and as other bodies concur with it less in acting, so its mind is more capable of understanding distinctly' (E 2p13s). See also E 4p389, 5p39. See also Alexandre Matheron (1988), Individu et communauté chez Spinoza (Paris: Éditions de Minuit), 43-51.

${ }^{25}$ Indeed, Spinoza differentiates between conduct guided by command (obedience) and conduct guided by knowledge of truth (love): the conduct is externally the same, and the former can lead into the latter (TTP $16 / 238$ [Note 34]).
} 
My second objector might worry how my criticism of self-cultivation be attributed to Spinoza when self-cultivation is the central concern of his most famous and profound text. My argument is that any account of the advance of reason cannot dwell on self-cultivation, but rather must include politics. But in the Ethics, Spinoza specifically prides himself on offering an account of what the mind can do to moderate the affects (E 3Pref).

Again, I can accept this point without damage. While I am proposing that politics is a necessary condition for mass popular rationality, I can grant that it is merely a supportive condition for individual rationality. In other words, I grant that it is possible that some individuals might develop their reason even under the most adverse political conditions (due to some lucky convergence of causes in their particular case). This gloss leads to a view of the Ethics and the political texts as complementary to one another, offering the individual and the sociological perspective respectively. We know that sometimes philosophical reflection (or artistic or narrative inspiration) can have significant effects on an individual's development of reason. The Ethics provides a guidebook for this to occur; an individual already motivated to refine their reason may find it very helpful. But we also know that there are broader sociological patterns of causation which mean that a widespread transformation of reason will not occur simply on the basis of the availability of helpful philosophical materials. If the political structure of society does not support a pluralistic egalitarian ethos, then most people will neither have the motivation to be interested in the Ethics, nor have the inclination to be receptive to artistic representations of its message: Spinoza's political texts work to determine the conditions that would be conducive to the widespread uptake of Spinozist rationality, and in particular, its central feature of egalitarianism and respect for differences.

Furthermore, even the already-motivated individual, reading the Ethics to improve their own reason, cannot afford to ignore politics. This is because any human being, even the 
most exceptional philosopher, is not self-caused: they do not have 'absolute power over [their] actions', nor are they 'determined only by [themself]' (E 3Pref). Rather, they need continual interaction with things outside of their nature to preserve themself. This being the case, Spinoza argues that '[t]he virtue of a free man is seen to be as great in avoiding dangers as in overcoming them' (E 4p69): taking measures to shape the external world to support my individual reason does not show the weakness of my reason, but rather its strength. To provide a banal illustration: I do not stock chocolate in my pantry because I know that if it is there, I will unwisely eat it all at once.

While a healthy diet is important, the more fundamental basis for human preservation and progress of reason is being in a community of people striving for common advantage $(\mathrm{E}$ $4 \mathrm{p} 18 \mathrm{~s})$. This is not easy to achieve, because insofar as people are subject to the passions, they do not agree in nature with one another (E 4p32-7): they often strive for partial and private ends, pitting themselves against each other and upsetting one another. Spinoza himself found his passions inflamed by the political turmoil of life in the Dutch Republic of his time: except that he was restrained by his landlord, he nearly brought the rage of a murderous crowd onto himself by displaying a provocative sign after a political lynching. ${ }^{26}$ In order to live peacefully, is it necessary to restrain the affects of the community in which one lives, and this can be done through political institutions (E 4p37s2).

Thus, the key measure to support the wise person's reason, explicitly identified in the Ethics and carried through in the rest of Spinoza's writings, is politics. Rather than just 'thinking through' one's own place in the universe, the individual seeking to develop their reason should also minimise external threats and cultivate external supports to this development.

\footnotetext{
${ }^{26}$ Justin D. Steinberg (2013), 'Spinoza's Political Philosophy', in Edward N. Zalta (ed.), The Stanford Encyclopedia of Philosophy (Winter 2013 Edition).
} 


\section{Implications: the Politics of Spinozist Rationality}

I grant Lloyd's central contention: that Spinoza's gift to contemporary philosophy and to our current condition is a profound conception of reason as part of nature. But I have argued that there is a key dimension of the Spinozist insight that is lacking from Lloyd's reconstruction: a sociological account of reason's helps and hindrances. Why are people not kinder, more pluralist, less quick to appoint themselves as authoritative judges of their fellows' deficiencies? If we want to speak of reason and its possibilities, we need to do due diligence to understand its determinate causes, so far as we can. There is no use stipulating that human thought ought to be a certain way, when in fact there are determinate causes making it take another course. In result, a full account of Spinozist reason needs to include politics; Spinozist rationality is a political question. 


\section{References}

Deleuze, Gilles (1992), Expressionism in Philosophy: Spinoza, trans. Martin Joughin (New York: Zone Books).

Duffy, Simon (2011), 'The Joyful Passions in Spinoza's Theory of Relations', in Dimitris Vardoulakis (ed.), Spinoza Now (Minneapolis: University of Minnesota Press), 51-64.

Gatens, Moira and Lloyd, Genevieve (1999), Collective imaginings: Spinoza, past and present (London: Routledge).

Lloyd, Genevieve (1984), The man of reason: "male" and "female" in Western philosophy (Minneapolis: University of Minnesota Press).

--- (1994), Part of nature: self-knowledge in Spinoza's Ethics (Ithaca: Cornell University Press).

--- (1996), Spinoza and the Ethics (Routledge philosophy guidebooks; London; New York, NY: Routledge).

--- (2009), 'Dominance and Difference. A Spinozist Alternative to the Distinction Between 'Sex' and 'Gender", in Moira Gatens (ed.), Feminist Interpretations of Spinoza (Pensylvania), 29-41.

--- (2020 forthcoming), 'Reconsidering Spinoza's 'Rationalism”', Australasian Philosophical Review.

Matheron, Alexandre (1988), Individu et communauté chez Spinoza (Paris: Éditions de Minuit).

Spinoza, Benedictus de (1972), Spinoza Opera, ed. Carl Gebhardt (Heidelberg: Carl Winter).

Spinoza, Benedict de (1994), 'Ethics', in E. M. Curley (ed.), A Spinoza reader : the Ethics and other works (Princeton: Princeton University Press), 85-265. [=E]

Spinoza, Benedictus de (2000), Political Treatise, trans. Samuel Shirley (Indianapolis: Hackett). [=TP]

--- (2001), Theological-political treatise, trans. Samuel Shirley (Indianapolis, Ind.: Hackett Pub.). [=TTP]

Steinberg, Justin D. (2009), 'Spinoza on civil liberation', Journal of the History of Philosophy, 47 (1).

--- (2013), 'Spinoza's Political Philosophy', in Edward N. Zalta (ed.), The Stanford Encyclopedia of Philosophy (Winter 2013 Edition) (http://plato.stanford.edu/archives/win2013/entries/spinoza-political/). 